\title{
Modified atmosphere in minimally processed cauliflower conservation and quality
}

\section{Atmosfera modificada na conservação e qualidade da couve-flor minimamente processada}

\author{
Karina Aparecida Furlaneto ${ }^{1}$; Flávia Aparecida de Carvalho Mariano-Nasser²; \\ Juliana Arruda Ramos ${ }^{1}$; Giovanna Alencar Lundgren ${ }^{3}$; \\ Cibelli Magalhães Nuvolari ${ }^{1}$; Pedro Fernandes Fleury de Souza Lima ${ }^{4}$; \\ Maurício Dominguez Nasser ${ }^{5 *}$; Rogério Lopes Vieites ${ }^{6}$
}

\begin{abstract}
The objective of this work was to evaluate modified atmosphere effectiveness in minimally processed cauliflower aiming food safety maintenance for consumers, as conservation of product physical and chemical characteristics for better quality. Cauliflowers cv. Cindy were selected, washed, sanitized with sodium hypochlorite $\left(200 \mathrm{mg} \mathrm{L}^{-1}\right)$ and rinsed. After processing, they were immersed, one more time, in sodium hypochlorite solution $(50 \mathrm{ppm})$ and dried by the air. Portions of $200 \mathrm{~g}$ were made and placed in different atmospheres: $\mathrm{T} 1=0.05 \% \mathrm{CO}_{2}+23 \% \mathrm{O}_{2} ; \mathrm{T} 2=$ vacuum; $\mathrm{T} 3=$ tray of expanded polystyrene with polyvinyl chloride film (PVC) and $\mathrm{T} 4=6 \% \mathrm{CO}_{2}+4 \% \mathrm{O}_{2}+90 \% \mathrm{~N}_{2}$. The packages were stored in cold chamber at $5{ }^{\circ} \mathrm{C} \pm 1$ and $85 \% \pm 5$ of relative humidity. Analysis were performed every two days and the evaluated traits were: loss of fresh mass, respiratory activity, soluble solids, titratable acidity, $\mathrm{pH}$, reducing sugars, instrumental color, visual and microbiological analysis. The experimental design was completely randomized, in factorial design. Data were submitted to analysis of variance and means were compared using Tukey test at $5 \%$ of probability and regression analysis for storage period. Tray of expanded polystyrene with PVC delayed for two days product climacteric peak in relation to other modified atmosphere. Furthermore, it provided quality attributes maintenance. The best notes of visual appearance and the best intention of purchase were attributed to minimally processed cauliflower wrapped in modified atmosphere with $6 \% \mathrm{CO}_{2} .+4 \% \mathrm{O}_{2}$.
\end{abstract}

Key words: Storage. Brassica oleracea var. Botrytis L. Minimal processing. Sensory. Shelf life.

\section{Resumo}

O objetivo deste trabalho foi avaliar a eficácia da utilização da atmosfera modificada em couve-flor minimamente processada, visando manter a segurança do alimento ao consumidor, além das suas características físico-químicas, mantendo sua qualidade. Foi utilizada couve-flor cv. Cindy, a qual

\footnotetext{
${ }^{1}$ Discentes de Doutorado em Energia na Agricultura, Departamento de Horticultura, Faculdade de Ciências Agronômicas, UNESP, Botucatu, SP, Brasil. E-mail: karina_furlaneto@globo.com; ju.a.ramos@globo.com; cibellinutri@hotmail.com

${ }^{2}$ Pesquisadora, Pós-doc, Departamento de Horticultura, Faculdade de Ciências Agronômicas, UNESP, Botucatu, SP, Brasil. E-mail: flaviamariano1@hotmail.com

${ }^{3}$ Discente de Doutorado, em Ciências da Nutrição, UFPB, João Pessoa, PB, Brasil. E-mail: giolundgren@gmail.com

${ }^{4}$ Eng $^{\circ}$ Agr $^{\circ}$, Faculdade de Ciências Agronômicas, UNESP, Botucatu, SP, Brasil. E-mail: pedro fleury@globo.com

${ }^{5}$ Discente de Doutorado em Horticultura, Departamento de Horticultura, Faculdade de Ciências Agronômicas, UNESP, Botucatu, SP, Brasil. E-mail: mdnassser@apta.sp.gov.br

${ }^{6}$ Prof. Titular, Departamento de Horticultura, Faculdade de Ciências Agronômicas, UNESP, Botucatu, SP, Brasil. E-mail: vieites@ fca.unesp.br

* Author for correspondence
} 
foi selecionada, lavada, higienizada com hipoclorito de sódio $\left(200 \mathrm{mg} \mathrm{L}^{-1}\right)$ e enxaguada. Após o processamento, foi novamente imersa em solução de hipoclorito de sódio $(50 \mathrm{ppm})$ e seca ao ar. Em seguida porções de $200 \mathrm{~g}$ foram acondicionadas em diferentes atmosferas, T1: $0,05 \% \mathrm{CO}_{2}+23 \% \mathrm{O}_{2}$; T2: Vácuo; T3: Bandeja de poliestireno expandido com filme de policloreto de vinila (PVC) e T4: 6 $\% \mathrm{CO}_{2}+4 \% \mathrm{O}_{2}+90 \% \mathrm{~N}_{2}$. As embalagens foram armazenadas em câmara fria a $5 \pm 1{ }^{\circ} \mathrm{C}$ e $85 \pm 5 \%$ de umidade relativa. As análises foram realizadas a cada dois dias, quanto à perda de massa, atividade respiratória, sólidos solúveis, acidez titulável, $\mathrm{pH}$, açúcares redutores, cor instrumental, análise visual e análise microbiológica. O delineamento experimental utilizado foi inteiramente casualizado (DIC), em esquema fatorial. Os dados foram submetidos à análise de variância e as médias foram comparadas por meio do teste de Tukey com $5 \%$ de probabilidade, fez-se regressão para as análises no tempo de armazenamento. A bandeja de poliestireno expandido com filme de PVC atrasou por dois dias o pico climatérico do produto em relação às demais atmosferas modificadas, além de proporcionar a manutenção dos atributos de qualidade. As melhores notas de aparência visual e a melhor intenção de compra foram atribuídas para a couve-flor minimamente processada acondicionada na atmosfera modificada ativa com $6 \% \mathrm{CO}_{2 .}+4 \% \mathrm{O}_{2}$.

Palavras-chave: Armazenamento. Brassica oleracea var. botrytis L. Processamento mínimo. Sensorial. Vida-útil.

\section{Introduction}

Changes in economic, social and technological sectors, in addition to the demand for a better quality of life by consumers require the market more offer products called convenience, such as minimally processed ones. Therefore, this field of processed fruits and vegetables becomes tendency and in expansion. They are suitable because of preparation time reduction, added value, greater production utilization, standardization, postharvest losses reduction and greater efficiency in waste management (MATTIUZ et al., 2004; RUSSO et al., 2012a).

Although the advantages of processed products, there are problems with their conservation, whereas they are damaged plant tissues (RINALDI et al., 2009; KLUGE et al., 2010). They present a shorter shelf-life when compared to the whole product due to damage caused by cutting, internal tissues are exposed causing cellular stress, resulting accelerated metabolism, increasing respiration rate and ethylene production (KLUGE et al., 2006).

The use of modified atmosphere is an effective method in shelf-life prolongation with different responses depending on product stored (SILVA et al., 2009). This technique has as a basic principle reduce $\mathrm{O}_{2}$ concentration and increase $\mathrm{CO}_{2}$, influencing physiological and biochemical processes of minimally processed product, as well as reduction of microbial proliferation (DAREZZO, 2000; ARRUDA et al., 2011).

Cauliflower is a vegetable rich in minerals such as potassium, important vitamins for human body, in addition to fiber, low calorie, antioxidants and anticancer compounds (glucosinolates). However, it is a product with high post-harvest perishability, presents high metabolism (high respiration rate) and high water loss being convenient control oxygen, temperature and relative humidity during storage avoiding quality losses (MICELI et al., 2015; MAY et al., 2007; BRACKMANN et al., 2005). Another problem observed during conservation and commercialization is the appearance of fungi, which makes unfeasible commercialization and consumption of this vegetable (SOUZA et al., 2010).

According to Miceli et al. (2015), minimally processed cauliflower is considered new at market and with few scientific researches. Factors as raw material quality, post-harvest treatments, packaging and storage conditions may significantly affect market and consumers acceptance. Therefore, the objective of this work was to evaluate the effectiveness of modified atmosphere use in freshly processed cauliflower, in order to maintain food safety to consumer, in addition to their sensorial and physicochemical characteristics. 


\section{Material and Methods}

Inflorescences of cauliflower cv. Cindy, acquired in a commercial production at municipality of Sorocaba were used. After harvested vegetables were immediately transported to Laboratory of Fruit and Vegetable Post-Harvest, Department of Horticulture, São Paulo State University, School of Agriculture, Botucatu, Brazil.
The lot was selected aiming homogenization for injuries and diseases absence. Cauliflower was washed in running tap water, sanitized with sodium hypochlorite $(\mathrm{NaClO})$ at $200 \mathrm{mg} \mathrm{L}^{-1}$ for 15 minutes followed by rinsing and manually processed in florets. After cutting they were placed one more time in sodium hypochlorite solution $\left(50 \mathrm{mg} \mathrm{L}^{-1}\right)$ for 15 minutes and dried by air. Subsequently, 200 g portions were packed in the followed treatments (Table 1).

Table 1. Active modified atmospheres applied to minimally processed cauliflowers.

\begin{tabular}{cc}
\hline Treatments & Active modified atmospheres \\
\hline 1 & $0,05 \% \mathrm{CO}_{2}+23 \% \mathrm{O}_{2}$ (Control) \\
2 & Vacuum \\
3 & Expanded polystyrene tray covered with PVC \\
4 & $6 \% \mathrm{CO}_{2}+4 \% \mathrm{O}_{2}+90 \% \mathrm{~N}_{2}$ \\
\hline
\end{tabular}

Transparent polyethylene nylon plastic bags (vacuum) of high oxygen barrier $\left(10 \mathrm{~cm}^{3}\right.$ day $\left.{ }^{-1}\right)$ and water vapour $\left(5 \mathrm{~g} \mathrm{~m}^{-2}\right.$ day $\left.^{-1} \mathrm{~atm}^{-1}\right)$ and expanded polystyrene trays coated with polyvinyl chloride film (PVC) with $0.020 \mathrm{~mm}$ thick were used. Treatment 4 gases mixture was purchased from White Martins and the process consisted of forming vacuum inside the package followed by injection of gas mixture through cylinder coupled in a TEC MAQ ${ }^{\circledR}$ vacuum sealer and closed immediately. In case of control treatment, it was closed with ambient air. The packages were storage in cold chamber of $5^{\circ} \mathrm{C} \pm 1$ and $85 \% \pm 5$ relative humidity.

Analysis were performed every two days, resulting in six storage period: at the day of storage, 2, 4, 6, 8 and 10 days after storage. The evaluated traits were: loss of fresh mass, respiratory activity, soluble solids, titratable acidity, $\mathrm{pH}$, reducing sugars, instrumental color, visual and microbiological analysis.

Loss of mass was determined by weighing packed fruits before and after storage with a semi analytical scale expressing the result in percentage (\%).
The respiratory activity was determined by $\mathrm{CO}_{2}$ released in each package, following guidelines of methodology adapted by Bleinroth et al. (1976), using equation 1.

$$
\mathrm{TCO}_{2}=\frac{2.2 x(A-B) \times V 1}{P \times T \times V 2} \quad \text { (Equation 1) }
$$

Where, $\mathrm{TCO}_{2}$ is the respiratory activity in $\mathrm{mL}$ of $\mathrm{CO}_{2} \mathrm{~kg}$ de fruta $^{-1}$ hora $^{-1}$; $\mathrm{A}$ is standard $\mathrm{HCl}$ volume used for titration of standard potassium hydroxide before $\mathrm{CO}_{2}$ absorption (white); $\mathrm{B}$ is standard $\mathrm{HCl}$ volume used for titration of standard potassium hydroxide after $\mathrm{CO}_{2}$ absorption; $\mathrm{V} 1$ is potassium hydroxide volume used in $\mathrm{CO}_{2}$ absorption $(\mathrm{mL}) ; \mathrm{P}$ is minimally processed cauliflower mass $(\mathrm{kg})$; $\mathrm{T}$ is metabolic reactions time (hora); V2 is potassium hydroxide volume used in titration $(\mathrm{mL}) ; 2.2$ is a constant due to $\mathrm{CO}_{2}$ equivalent (44/2), multiplied by $\mathrm{HCl}$ concentration $0.1 \mathrm{~N}$.

Soluble solids ( ${ }^{\circ} \mathrm{Brix}$ ), hydrogenation potential $(\mathrm{pH})$ and titratable acidity (\%) were determined following Adolfo Lutz Institute's Analytical Standards (BRASIL, 2008). Reducing sugars were 
estimated according to methodology describe by Nelson (1944) adapted by Somogy (1945) with Micronal B 382 spectrophotometer, reading at 535 $\eta \mathrm{m}$ and results expressed in percentage (\%).

Instrumental colour was determined by evaluating two points on florets of freshly processed cauliflower using Konica Minolta colorimeter (Chroma meter, CR 400), with reading values (L*, Croma and Hue) (MINOLTA, 1998).

In visual analysis consumers evaluated appearance and purchase intention to minimally processed cauliflower in different modified atmospheres. The judging committee consisted of 30 tasters for each day of analysis. A scale of grades between 1 to 5 was used, where 1 was "terrible" and 5 was "great" for visual appearance and 1 "certainly would not buy" and 5 "certainly would buy".
The required microbiological analyses (Coliforms at $45{ }^{\circ} \mathrm{C} \mathrm{g}^{-1}$ and Salmonella sp $25 \mathrm{~g}^{-1}$ ) were performed by the current legislation RDC 12/01 for minimally processed products.

The experimental design was completely randomized (DIC), in a factorial scheme $4 \times 6$ (treatment $\mathrm{x}$ storage). Data were submitted to analysis of variance and means were compared by Tukey test with $95 \%$ probability, and for storage period, regression was done.

\section{Results and Discussion}

Mean square and levels of significance for evaluated traits were shown in Table 2 along 10 days of storage. Treatments, storage period and the interaction between them were not significant for Luminosity and Hue.

Table 2. Mean square values and significance levels in minimally processed cauliflowers placed in different active modified atmospheres for loss of mass (LM), soluble solids (SS), titratable acidity (TA), pH, reducing sugar (RS), luminosity (L), Croma (C), ${ }^{\circ} \mathrm{Hue}$, visual appearance (VA) and purchase intention (PI).

\begin{tabular}{lccccc}
\hline \multirow{2}{*}{ Cause of variation } & \multicolumn{5}{c}{ Mean Square } \\
\cline { 2 - 5 } \multicolumn{1}{c}{ LM } & $\mathrm{SS}$ & $\mathrm{TA}$ & $\mathrm{pH}$ & $\mathrm{RS}$ \\
\hline Treatment & $3,70^{* *}$ & $0,27^{* *}$ & $0,25^{*}$ & $0,39^{* *}$ & $0,42^{* *}$ \\
Storage time & $1,07^{* *}$ & $0,65^{* *}$ & $1,89^{* *}$ & $0,19^{* *}$ & $0,73^{* *}$ \\
Treatment * Storage time & $0,30^{* *}$ & $0,10^{*}$ & $0,14^{*}$ & $0,03^{* *}$ & $0,05^{* *}$ \\
\hline Overall mean & 0,318 & 5,88 & 2,0 & 6,93 & 1,93 \\
\hline C.V. & 33,3 & 4,0 & 12,9 & 0,9 & 8,3 \\
\hline & $\mathrm{L}$ & $\mathrm{C}$ & ${ }^{\circ} H u e$ & $\mathrm{AV}$ & $\mathrm{PI}$ \\
\hline Treatment & $145,0^{\text {ns }}$ & $17,4^{* *}$ & $155,3^{\text {ns }}$ & $37,7^{* *}$ & $41,3^{* *}$ \\
Storage time & $204,2^{\text {ns }}$ & $93,0^{* *}$ & $164,5^{\text {ns }}$ & $64,4^{* *}$ & $65,8^{* *}$ \\
Treatment * Storage time & $111,1^{\text {ns }}$ & $51,7^{* *}$ & $123,5^{\text {ns }}$ & $3,80^{* *}$ & $3,46^{* *}$ \\
\hline Overall mean & 89,4 & 26,7 & 100,1 & 3,62 & 3,59 \\
\hline C.V. & 11,7 & 16,3 & 11,5 & 28,8 & 31,1 \\
\hline
\end{tabular}

$* *(p<0.01) ; *(p<0.05) ;{ }^{\text {ns }}$ (not significant). CV: Coefficient of experimental variation.

Loss of mass increased linearly with storage time (Figure 1), independently of package type ( $\mathrm{p}$ $<0.01)$. It was observed products stored in trays with PVC film have shown the largest loss of mass $(1.62 \%)$. In contrast, vegetables in it treatment presented the lowest respiratory activity (Figure 2) in relation to others treatments. PVC film has water vapour transmission higher than $8 \mathrm{~g} \mathrm{~m}^{-2}$ day $^{-1} \mathrm{~atm}^{-1}$, classified as low water vapour barrier and polyethylene is considered as high barrier (4 $\left.\mathrm{g} \mathrm{m}^{-2} \mathrm{dia}^{-1} \mathrm{~atm}^{-1}\right)$ (CHITARRA; CHITARRA, 2005). Probably PVC allowed escape of water lost by cauliflower to environment while the others atmospheres kept it retained inside the package, seeming less loss of mass. 
Figure 1. Loss of mass (\%) in minimally processed cauliflowers placed in different modified atmospheres, during 10 days of storage $\left(5^{\circ} \mathrm{C} \pm 1\right.$ and $\left.85 \% \pm 5 \mathrm{RU}\right)$.

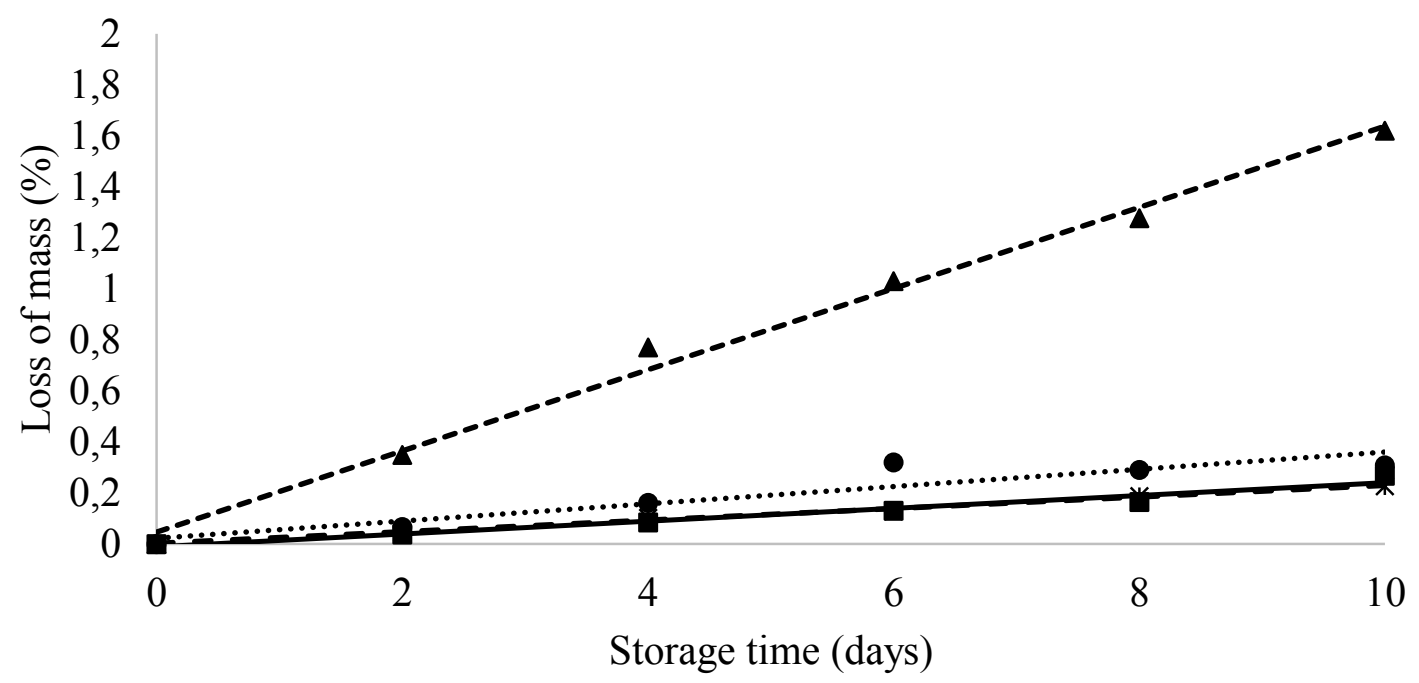

Control (T1): $\mathrm{Y}=-0,012+0,025 \mathrm{x}\left(\mathrm{R}^{2}=0,96\right)$

- Vacuum (T2): $\mathrm{Y}=0,006+0,04 \mathrm{x}\left(\mathrm{R}^{2}=0,86\right)$

$\Delta$ Tray + PVC (T3): $\mathrm{Y}=0,04+0,159 \mathrm{x}\left(\mathrm{R}^{2}=0,99\right)$

$* 4 \% \mathrm{O} 2+6 \% \mathrm{CO} 2(\mathrm{~T} 4): \mathrm{Y}=0,002+0,023 \times\left(\mathrm{R}^{2}=0,99\right)$

Figure 2. Respiratory activity $\left(\mathrm{ml} \mathrm{CO}_{2} \mathrm{Kg}^{-1} \mathrm{~h}^{-1}\right)$ in minimally processed cauliflowers placed in different modified atmospheres, during 10 days of storage $\left(5^{\circ} \mathrm{C} \pm 1\right.$ and $\left.85 \% \pm 5 \mathrm{RU}\right)$.

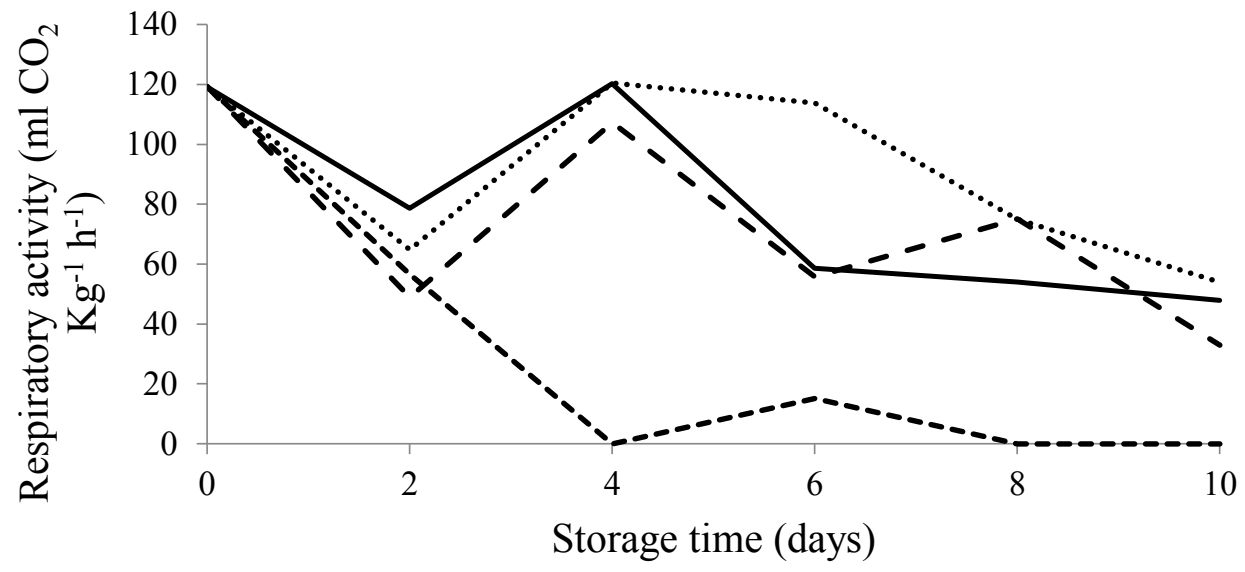

Control ........ Vacuum ---.. Tray + PVC - - - $4 \% \mathrm{O} 2+6 \% \mathrm{CO} 2$

According to Simón et al. (2008), loss of mass is mainly due to loss of water by plant transpiration and water evaporation. This decrease in vegetable mass is influenced by package vapour transmission rate. Working with minimally processed cauliflower stored in PCV film, perforated PCV and polypropylene bags, the same authors, observed similar behaviour as in this research, less mass loss and greater humidity inside the films which has less vapour transmission (polypropylene), resulting condensation inside the package. 
Products conditioned in active modified atmosphere $\left(6 \% \mathrm{CO}_{2}\right)$, control and vacuum obtained the lowest mass losses $0.22,0.26$ and $0.30 \%$, respectively. These reductions, probably, did not cause product quality loss, as Chitarra and Chitarra (2005) once mentioned, only moisture losses between $3 \%$ and $5 \%$ may make the vegetable unappropriated to consumption. Nevertheless, when there is humidity excess inside modified atmosphere, it may favour microorganisms growth causing deterioration. In relation to cauliflower post-harvest conservation, it is an important factor as this vegetable presents high water loss and problems with microbiological contamination during commercialization.

The respiratory rate has a peak for minimally processed products (MPP) for all treatments at the day of implantation (time zero) due to physical damage caused by raw material minimal processing which probably accelerated cauliflower respiratory rate. Rinaldi et al. (2008) found whole cabbage respiratory rate significantly lower than minimally processed product under a modified atmosphere at $5^{\circ} \mathrm{C}$. The respiratory peak of freshly minimally processed cauliflower wrapped in expanded polystyrene tray covered with PVC film was lower (15.2 $\mathrm{mL} \mathrm{CO}_{2} \mathrm{~kg}^{-1} \mathrm{~h}^{-1}$ ) (Figure 2) and delayed until six days after storage compared to other treatments whose respiratory peak anticipated to four days after storage and presented the highest intensity (107.3 to $120.5 \mathrm{~mL} \mathrm{CO}_{2} \mathrm{~kg}^{-1} \mathrm{~h}^{-1}$ ) (Figure 2). This delay in climacteric peak is important in post-harvest conservation, as after it catabolic reactions event (degradations) occur resulting in senescence (death of tissues) (CHITARRA; CHITARRA, 2005).
Soluble solids contents were influenced by storage period $(\mathrm{p}<0.05)$ (Figure 3) in MPP in control, vacuum and active modified atmosphere $\left(6 \% \mathrm{CO}_{2}\right.$ and $\left.4 \% \mathrm{O}_{2}\right)$ treatments. Decrease of these contents in 10 days of shelf was observed from $6.3{ }^{\circ}$ Brix at the moment of experiment installation to $5.9^{\circ} \mathrm{Brix}$ (control and active modified atmosphere) and $5.1{ }^{\circ}$ Brix (vacuum). Probably the contents decrease occurred due to carbohydrates and organic consumption via glycolysis as these treatments presented the highest respiration rates. The minimally processed cauliflower wrapped in expanded polystyrene tray with PVC film did not show significant statistical difference during storage ( $p>0.05$ ) maintaining its contents during 10 days ( 6.3 to $5.9^{\circ}$ Brix). Silva et al. (2009) cited in minimally processed products it is common to increase soluble solids contents in response to moisture loss during storage, which may not be possible to observe in present work because its small mass losses.

Similar behaviour was observed for titratable acidity contents (Figure 4) as function of shelf life $(p<0.05)$. In all MPP treatments reduction was observed along 10 days of storage with small acidity increase from four days after storage. It was observed higher organic acids consumption (43.90\% on average) for control, vacuum and $6 \% \mathrm{CO}_{2}+4 \%$ $\mathrm{O}_{2}$ until the fourth day of storage coinciding with climacteric peak of respiratory rate. The increase in acidity after this period, in all treatments, may be explained by minimally processed yellow pepper research made by Kluge et al. (2014); acidification occurs with increasing carbon dioxide intracellular concentration due to increased respiratory activity. 
Figure 3. Soluble solids ( ${ }^{\circ}$ Brix) in minimally processed cauliflowers placed in different modified atmospheres, during 10 days of storage $\left(5^{\circ} \mathrm{C} \pm 1\right.$ and $\left.85 \% \pm 5 \mathrm{RU}\right)$.

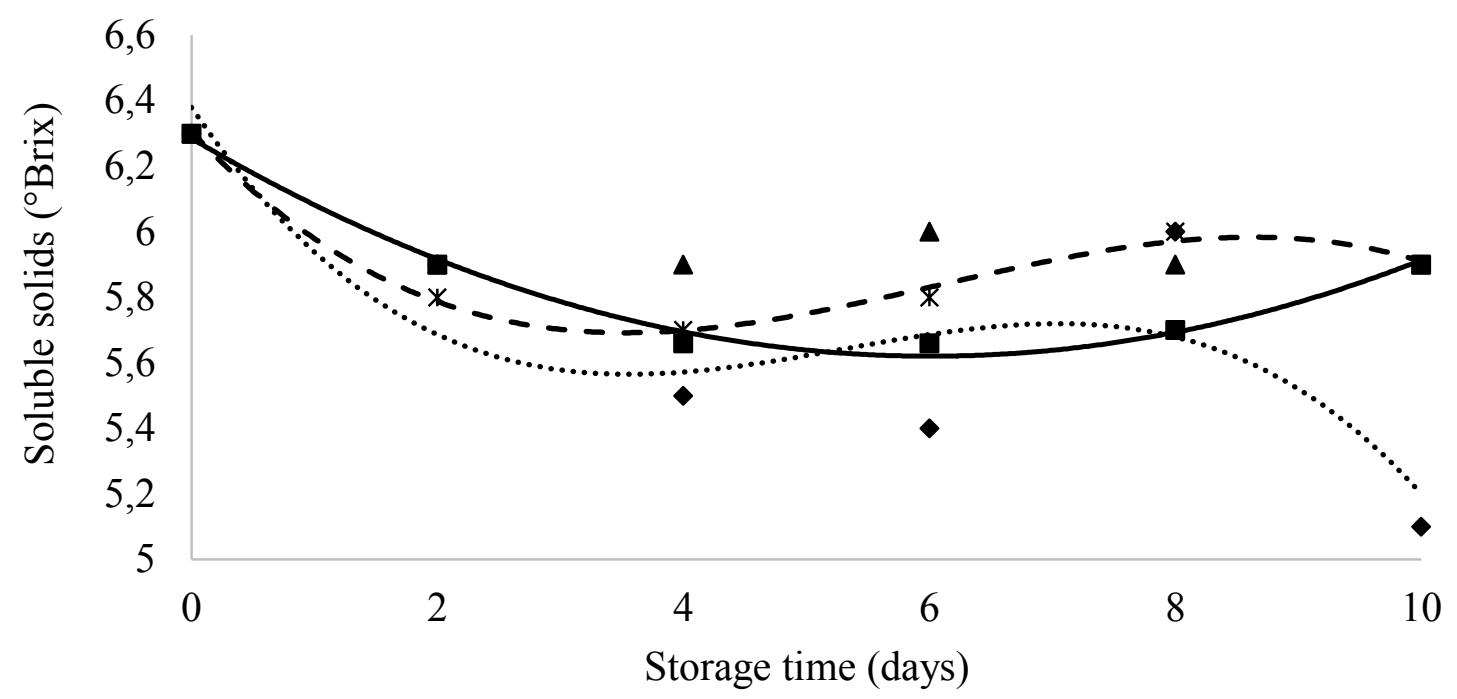

-Control (T1): $\mathrm{Y}=6,311-0,228 \mathrm{x}+0,019 \mathrm{x}^{2}\left(\mathrm{R}^{2}=0,98\right)$

- Vacuum (T2): $Y=6,404-0,554 x+0,118 x^{2}-0,007 x^{3}\left(R^{2}=0,78\right)$

$\Delta$ Tray + PVC (T3): ns

$* 4 \% \mathrm{O} 2+6 \% \mathrm{CO} 2(\mathrm{~T} 4): \mathrm{Y}=6,339-0,410 \mathrm{x}+0,084 \mathrm{x}^{2}-0,005 \mathrm{x}^{3}\left(\mathrm{R}^{2}=0,99\right)$

Figure 4. Titratable acidity contents (\%) in minimally processed cauliflowers placed in different modified atmospheres, during 10 days of storage $\left(5^{\circ} \mathrm{C} \pm 1\right.$ and $\left.85 \% \pm 5 \mathrm{RU}\right)$.

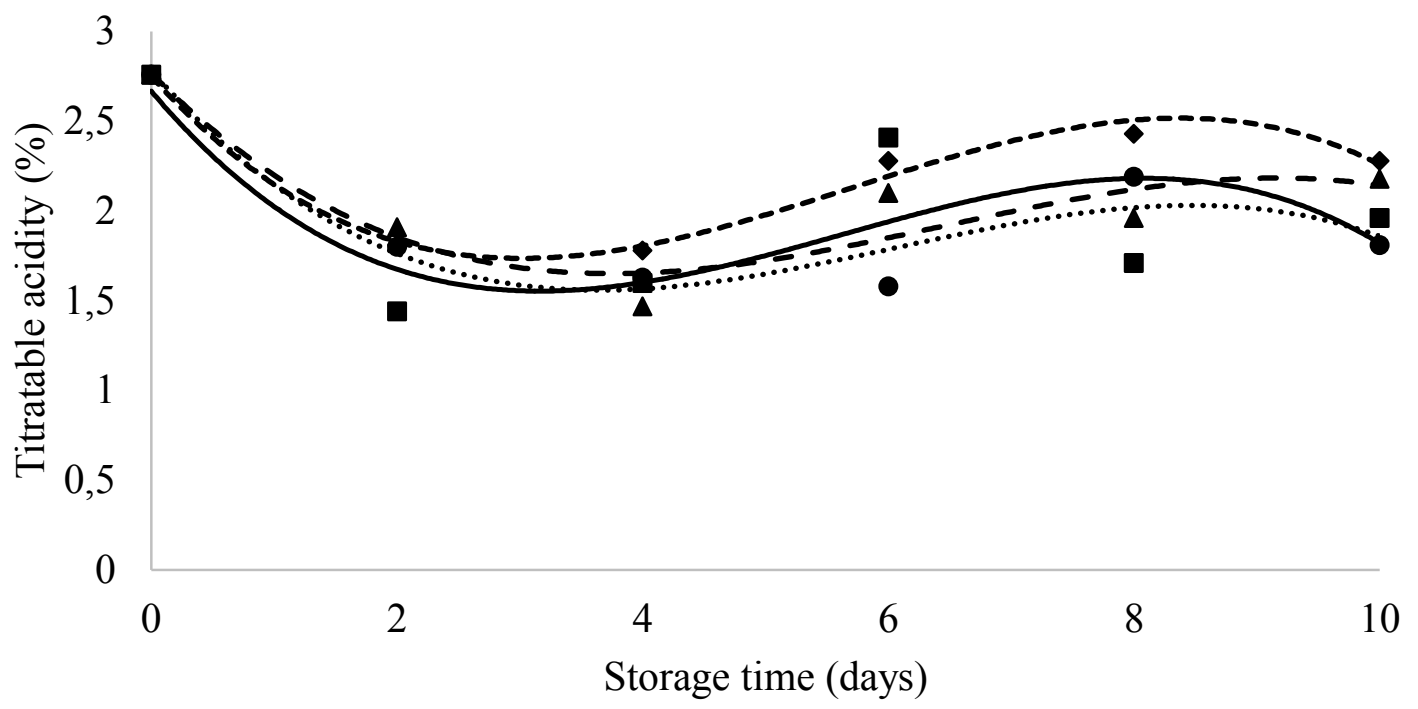

Control (T1): $\mathrm{Y}=2,67-0,811 \mathrm{x}+0,178 \mathrm{x}^{2}-0,010 \mathrm{x}^{3}(\mathrm{R} 2=0,59)$

- Vacuum (T2): $\mathrm{Y}=2,78-0,786 \mathrm{x}+0,154 \mathrm{x}^{2}-0,008 \mathrm{x}^{3}\left(\mathrm{R}^{2}=0,91\right)$

- Tray + PVC (T3): $\mathrm{Y}=2,75-0,768 \mathrm{x}+0,173 \mathrm{x}^{2}-0,010 \mathrm{x}^{3}\left(\mathrm{R}^{2}=0,97\right)$

$\Delta 4 \% \mathrm{O} 2+6 \% \mathrm{CO} 2(\mathrm{~T} 4): \mathrm{Y}=2,77-0,692 \mathrm{x}+0,130 \mathrm{x}^{2}-0,007 \mathrm{x}^{3}\left(\mathrm{R}^{2}=0,85\right)$ 
Chitarra and Chitarra (2005) explain that organic acids are used as substrates in respiratory process or transformed into sugars. They are found as metabolic intermediates, at low concentrations, in vacuoles, available in stored energy form. However, products packed in tray and treatment with $6 \% \mathrm{CO}_{2}$ $+4 \% \mathrm{O}_{2}$ presented the highest levels at the end of storage, $2.28 \%$ and $2.18 \%$, respectively, evidencing maintenance of product quality. Rinaldi et al. (2009) researching minimally processed cabbage, in different modified atmospheres, found acidity levels decrease over 16 days of storage.
The minimally processed cauliflower $\mathrm{pH}$ values (Figure 5) showed increment during10 days of storage and statistical differences $(\mathrm{p}<0.01)$ for control, vacuum and $6 \% \mathrm{CO}_{2}+4 \% \mathrm{O}_{2}$ treatments. The lowest $\mathrm{pH}$ values were observed throughout storage for expanded polystyrene tray (6.7 to 6.68). Silva et al. (2009) mentioned $\mathrm{pH}$ values increment in several minimally processed products. Otherwise, this behaviour is not well known and may be as consequence of $\mathrm{CO}_{2}$ metabolism or elimination for vacuoles in response to acidity Rinaldi et al. (2009) and Kluge et al. (2014) cited in MPP surveys the increase in $\mathrm{pH}$ may occur due to microbiota growth during storage.

Figure 5. Values of $\mathrm{pH}$ in minimally processed cauliflowers placed in different modified atmospheres, during 10 days of storage $\left(5^{\circ} \mathrm{C} \pm 1\right.$ and $\left.85 \% \pm 5 \mathrm{RU}\right)$.

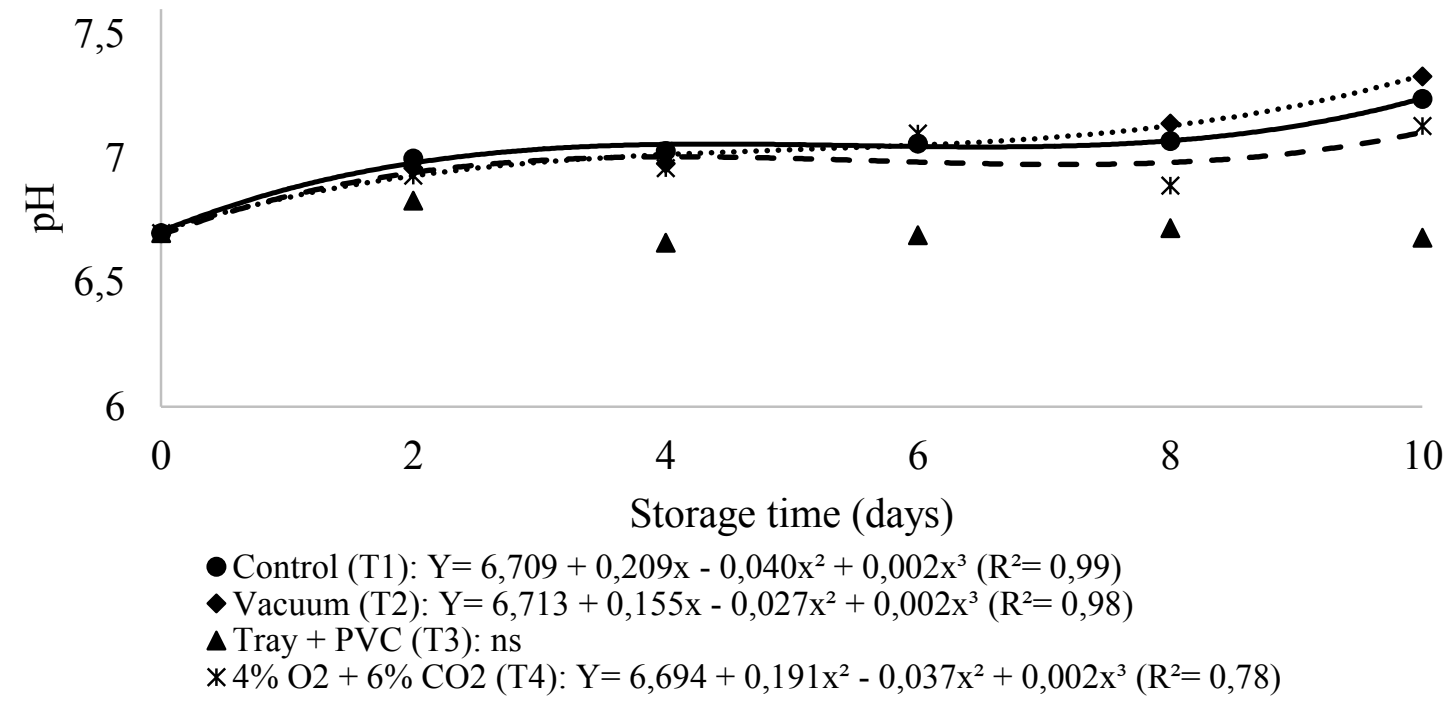

Reducing sugars contents (Figure 6) of minimally processed cauliflower were influenced by storage period $(p<0.01)$ decreasing their values during storage in all atmospheres. However, the highest contents were observed in cauliflower conditioned in tray with PVC film and 6\% $\mathrm{CO}_{2}+$ $4 \% \mathrm{O}_{2}(2.24 \%$ to $1.86 \%$ and $1.71 \%$, respectively). The lowest contents were observed in MPP control and vacuum throughout the storage (10 days), as this behaviour, possibly, was due to respiratory rate increase, resulting in greater carbohydrate reserves consumption of minimally processed cauliflower. A similar result was observed by Russo et al. (2012b), in research with minimally processed melon. Simón et al. (2008) reported reducing sugar contents had reduction ( $27 \%$ in 20 days of storage) throughout studied period for cauliflower MP being better conserved in non-perforated PVC.

The luminosity found at experiment implantation was 87.1 and $100.2^{\circ}$ Hue, being higher than values found in raw cauliflowers (79.5 and $88.9^{\circ} \mathrm{Hue}$ ) by Pellegrini et al. (2010). There was no difference 
between treatments $(\mathrm{p}>0.05)$ for luminosity, showing no treatment interfered with cauliflower darkening. The results for Hue angle also showed MPP of different treatments did not influence in colour change $(p>0.05)$ as there was no significant difference between different modified atmospheres. Sigrist (2002) did not find difference between cauliflowers in different packages for luminosity and Hue angle. Different response was observed by Olarte et al. (2009) when researching minimally processed cauliflowers stored in different types of PVC films, found small decline in Hue angle and luminosity during storage. The authors link this behavior to natural increase in cauliflowers metabolic activity.
The colour intensity, represented by Chroma (Figure 7), increased over storage time $(\mathrm{p}<0.01)$ from 22.2 at the moment of installation to 32.9, 27.0 and 28.6, respectively for control, vacuum and $6 \% \mathrm{CO}_{2}+4 \% \mathrm{O}_{2}$ treatments. Minimally processed cauliflowers packed in trays with PVC film increased Chroma until day six (30.6), followed by decline until the end of storage period (24.3), becoming more yellowish, losing vegetable characteristic colour. This increase in colour intensity may have occurred due to polyphenoloxidase enzymes activity and peroxidase degradative reactions. In addition to this, Simón et al. (2008) also found similar result, yellowing of cauliflower florets placed in nonperforated PVC.

Figure 6. Reducing sugar (\%) in minimally processed cauliflowers placed in different modified atmospheres, during 10 days of storage $\left(5^{\circ} \mathrm{C} \pm 1\right.$ and $\left.85 \% \pm 5 \mathrm{RU}\right)$.

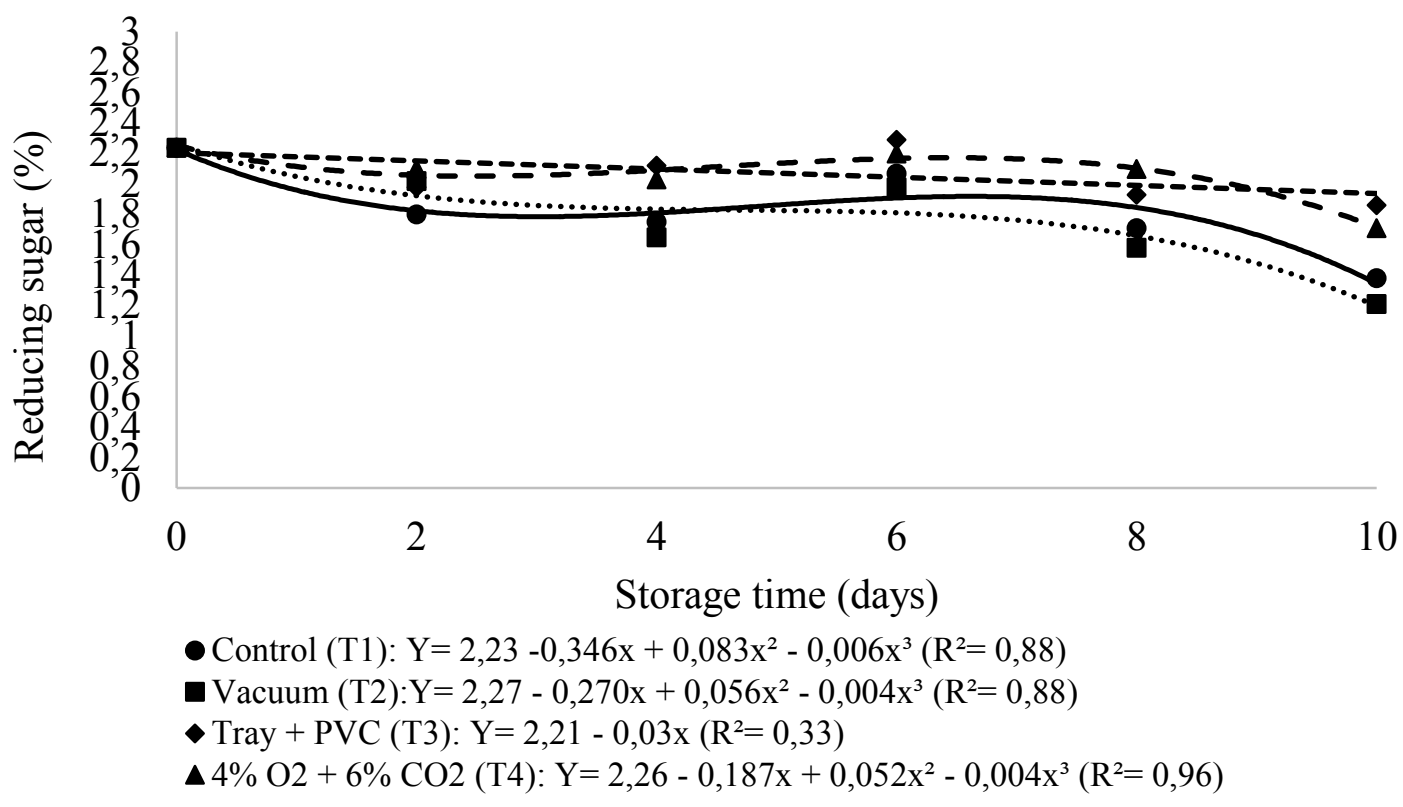


Figure 7. Croma of minimally processed cauliflowers placed in different modified atmospheres, during 10 days of storage $\left(5^{\circ} \mathrm{C} \pm 1\right.$ and $\left.85 \% \pm 5 \mathrm{RU}\right)$.

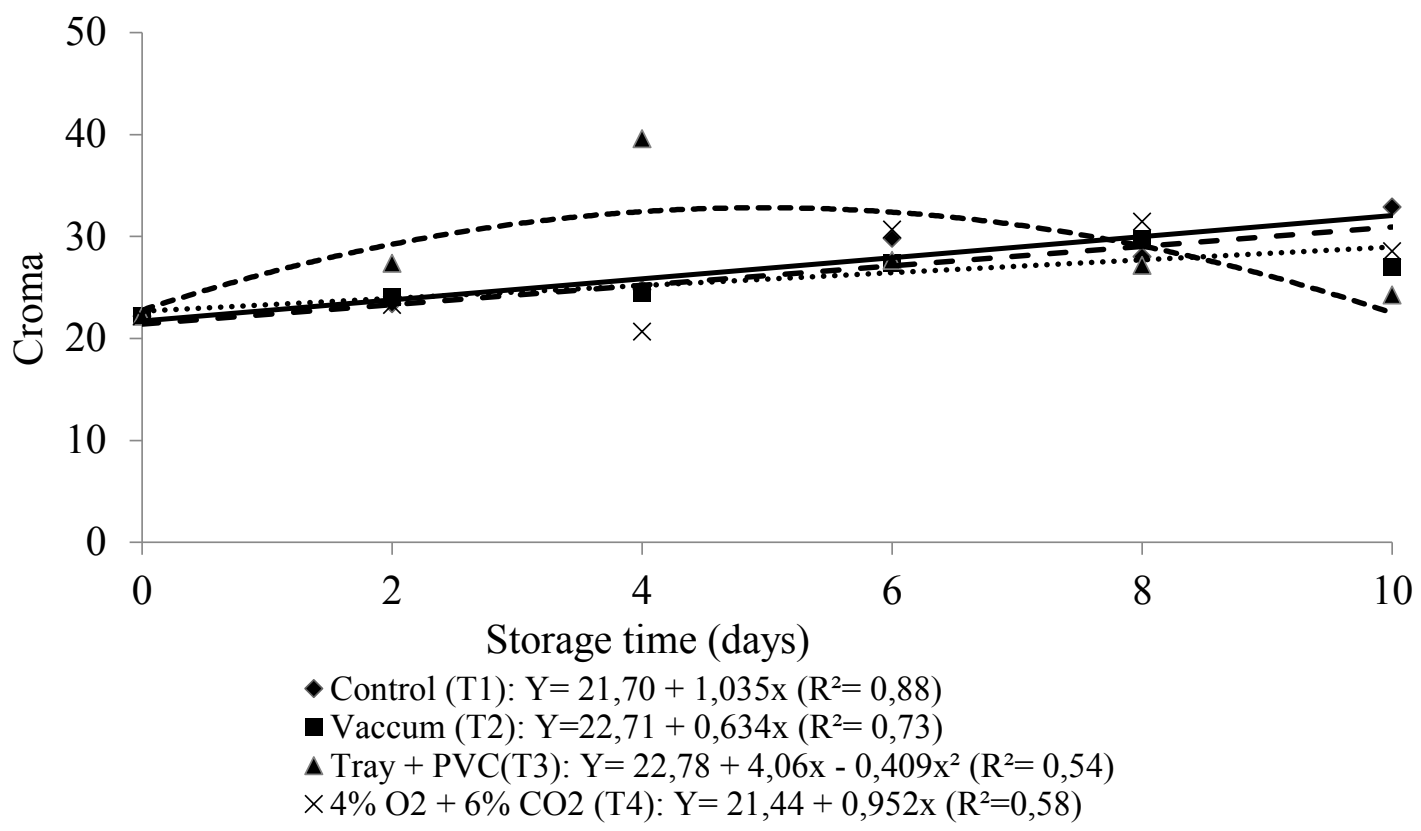

Figure 8. Visual appearance (notes) in minimally processed cauliflowers placed in different modified atmospheres, during 10 days of storage $\left(5^{\circ} \mathrm{C} \pm 1\right.$ and $\left.85 \% \pm 5 \mathrm{RU}\right)$.

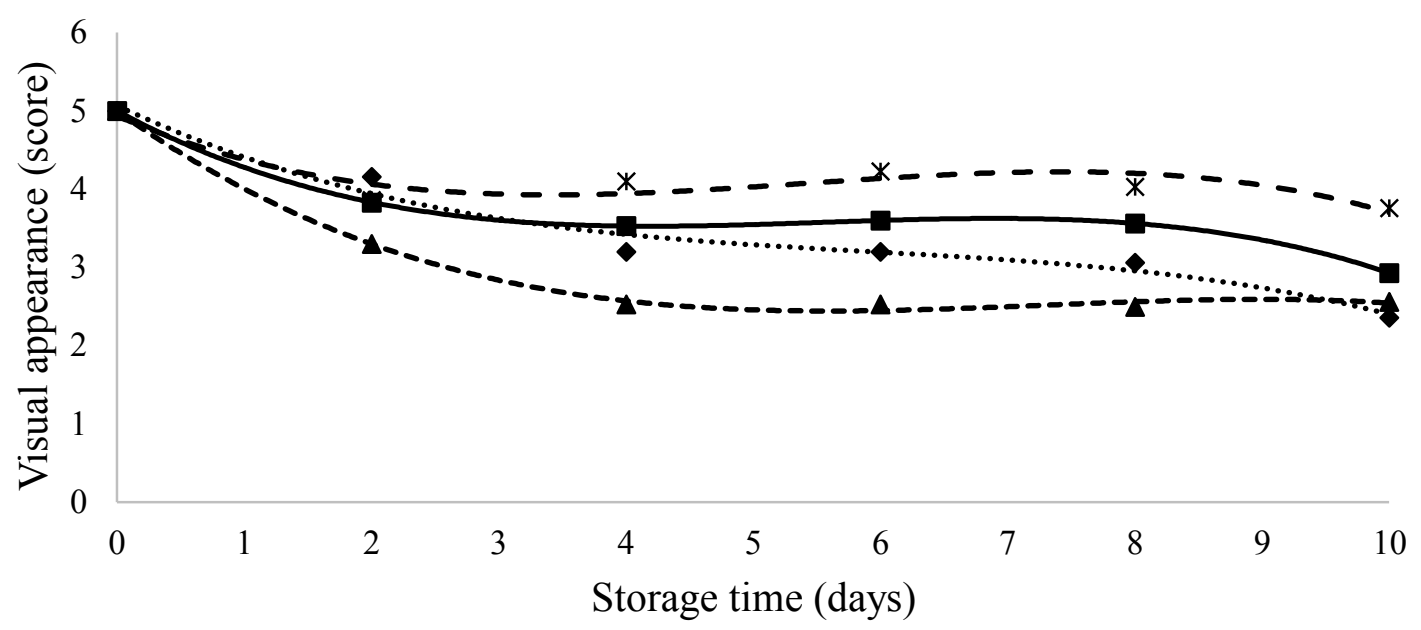

- Control (T1): $\mathrm{Y}=5,0-0,88 \mathrm{x}+0,170 \mathrm{x}^{2}-0,010 \mathrm{x}^{3}\left(\mathrm{R}^{2}=1,0\right)$

-Vacuum (T2): $\mathrm{Y}=5,06-0,76 \mathrm{x}+0,113 \mathrm{x}^{2}-0,006 \mathrm{x}^{3}\left(\mathrm{R}^{2}=0,97\right)$

$\Delta$ Tray + PVC (T3): $\mathrm{Y}=5,0-1,13 \mathrm{x}+0,160 \mathrm{x}^{2}-0,007 \mathrm{x}^{3}\left(\mathrm{R}^{2}=0,99\right)$

* 4\% O2 + 6\% CO2 (T4): $\mathrm{Y}=4,93-0,694 \mathrm{x}+0,148 \mathrm{x}^{2}-0,009 \mathrm{x}^{3}\left(\mathrm{R}^{2}=0,88\right)$ 
In Figure 8, scores for visual analysis were attributed by committee testers for different modified atmospheres over 10 days of storage ( $\mathrm{p}<0.01$ ). MPP in 6\% $\mathrm{CO}_{2}+4 \% \mathrm{O}_{2}$ treatment presented the highest notes during storage time (4.0), classified as good while the lowest notes were observed in expanded polystyrene trays with PVC (2.7 on average) classified as regular to poor due to yellowish coloration acquired during the storage. Similar results were found by Miceli et al. (2015) reporting scores reduction in minimally processed cauliflower 21 days of storage (5 to 2.7). In relation to Simón et al. (2008) research, cauliflowers wrapped in PVC presented the lowest notes to general appearance, however, showed increment in scoring at polypropylene material 20 days after storage.
The same behaviour was observed in purchase intention (Figure 9) showing consumers preference to cauliflower placed in $6 \% \mathrm{CO}_{2}+4 \% \mathrm{O}_{2}$ treatment with notes around 4.0 throughout storage. In the other hand, minimally processed cauliflower wrapped in expanded polystyrene trays covered with PVC and vacuum packages received the lowest notes demonstrating loss purchase intention from second day of storage (tray) and fourth day (vacuum).

Microbiological analyses (Table 3) confirmed satisfactory sanitary conditions of raw material used in accordance with current legislation (Resolution no. 12 of January 2, 2001 - National Sanitary Surveillance Agency - ANVISA), which determines absence of Salmonella sp. in $25 \mathrm{~g}$ of sample (BRASIL, 2001).

Figure 9. Purchase intantion (notes) in minimally processed cauliflowers placed in different modified atmospheres, during 10 days of storage $\left(5^{\circ} \mathrm{C} \pm 1\right.$ and $\left.85 \% \pm 5 \mathrm{RU}\right)$.

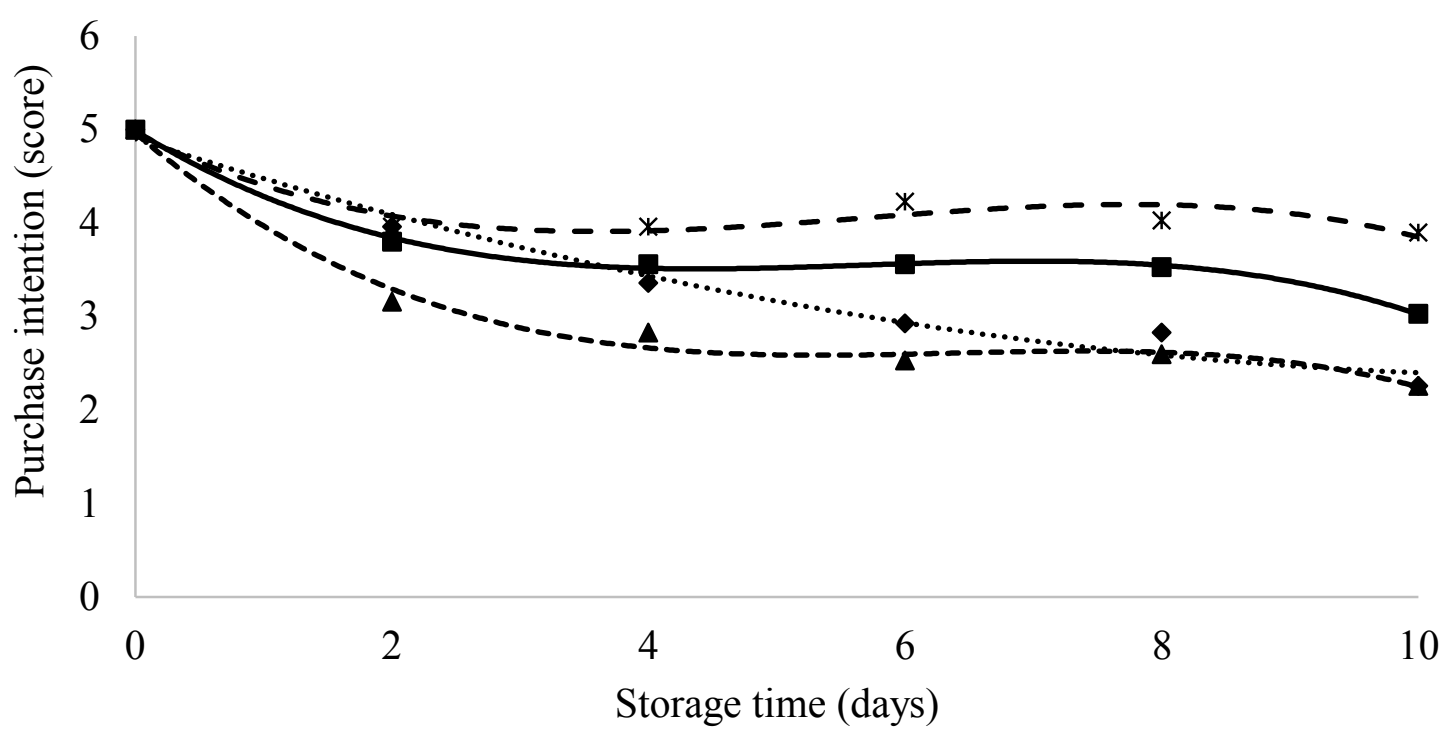

Control (T1): $Y=4,99-0,849 x+0,157 x^{2}-0,009 x^{3}\left(R^{2}=0,99\right)$

-Vacuum (T2): $\mathrm{Y}=4,90-0,443 \mathrm{x}+0,019 \mathrm{x}^{2}\left(\mathrm{R}^{2}=0,97\right)$

$\Delta$ Tray + PVC (T3): $\mathrm{Y}=4,96-1,18 \mathrm{x}+0,188 \mathrm{x}^{2}-0,010 \mathrm{x}^{3}\left(\mathrm{R}^{2}=0,98\right)$

* 4\% O2 + 6\% CO2 (T4): $\mathrm{Y}=4,96-0,683 \mathrm{x}+0,139 \mathrm{x}^{2}-0,008 \mathrm{x}^{3}\left(\mathrm{R}^{2}=0,92\right)$ 
Table 3. Total coliforms and E. coli quantification in minimally processed cauliflowers placed in different modified atmospheres, during 10 days of storage $\left(5^{\circ} \mathrm{C} \pm 1\right.$ and $\left.85 \% \pm 5 \mathrm{RU}\right)$.

\begin{tabular}{cccc}
\hline \multirow{2}{*}{ Time } & Cauliflower minimally processed & Total coliforms (NMP/g) & $\begin{array}{c}\text { E. coli } \\
\text { (NMP/g) }\end{array}$ \\
\hline DAY 0 & Raw material (cauliflower) & $<3$ & $<3$ \\
\hline \multirow{3}{*}{ DAY 6 } & Control (T1) & 9,1 & 9,1 \\
& Vacuum (T2) & 43 & 3,6 \\
\hline & Tray + PVC (T3) & 7,3 & $<3$ \\
& $6 \% \mathrm{CO}_{2}+4 \% \mathrm{O}_{2}(\mathrm{~T} 4)$ & 3,6 & $<3$ \\
\hline \multirow{2}{*}{ DAY 10 } & Control (T1) & 15 & 3,6 \\
& Vacuum (T2) & 43 & 3,6 \\
\hline & Tray + PVC (T3) & 15 & $<3$ \\
& $6 \% \mathrm{CO}_{2}+4 \% \mathrm{O}_{2}(\mathrm{~T} 4)$ & 3,6 & $<3$ \\
\hline
\end{tabular}

During minimally processed cauliflower storage (10 days) none of treatments presented total coliform and Escherichia coli above to value recommended by Brazilian legislation ( $10^{2}$ NMP per gram).

Cauliflower MP placed in different modified atmospheres presented food safety, as there was no contamination by Salmonella, total coliforms and E. coli, indicating presence of Good Manufacturing Practices and Product Manipulation. In this case, cauliflower is classified as good to human consumption based on microbiological standards in Brazilian legislation. Kluge et al. (2014) cited that use of cold, from product processing to final consumer, as well as researches aiming conservation techniques development is essential for maintaining food safety and minimally processed products.

\section{Conclusion}

The active modified atmosphere with $6 \%$ $\mathrm{CO}_{2}+4 \% \mathrm{O}_{2}$ is recommended for packaging minimally processed cauliflower, due to the best visual appearance and the best purchase intention attributed to this product.

\section{References}

ARRUDA, M. C.; JACOMINO, A. P.; TREVISAN, M. J.; JERONIMO, E. M.; MORETTI, C. L. Atmosfera modificada em laranja Pêra minimamente processada. Bragantia, Campinas, v. 70, n. 3, p. 664-671, 2011.

BLEINROTH, E. W.; ZUCHINI, A. G.; POMPEO, R. M. Determinação das características e mecânicas de variedades de abacate e sua conservação pelo frio. Coletânea ITAL, Campinas, v. 7, n. 1, p. 29-81, 1976.

BRACKMANN, A.; TREVISAN, J. N.; MARTINS, G. A. K.; FREITAS, S. T. de; MELLO, A. M. de. Qualidade pós-colheita de couve-flor Teresópolis gigante tratada com etileno, absorvedor de etileno e 1-metilciclopropeno. Ciência Rural, Santa Maria, v. 35, n. 6, p. 1444-1447, 2005.

BRASIL. Ministério da Saúde. Agência Nacional de Vigilância Sanitária - ANVISA. Resolução RDC 12, de 02 de janeiro de 2001. Regulamento técnico sobre padrões microbiológicos para alimentos. Diário Oficial [da] União, Brasília, 10 jan. 2001. Seção 1.

BRASIL - MINISTÉRIO DA SÁUDE. Instituto Adolfo Lutz. Métodos físicos e químicos para análise de alimentos. 4. ed. São Paulo: Instituto Adolfo Lutz, 2008. $1020 \mathrm{p}$.

CHITARRA, M. I. F.; CHITARRA, A. B. Pós-colheita de frutas e hortaliças: fisiologia e manuseio. 2. ed. Lavras: UFLA, 2005. $785 \mathrm{p}$.

DAREZZO, H. M. Processamento mínimo de alface (Lactuca sativa L.). In: ENCONTRO NACIONAL SOBRE PROCESSAMENTO MÍNIMO DE FRUTAS E HORTALIÇAS, 2., 2000, Viçosa, MG. Palestras... Viçosa, MG: UFV, 2000. p. 117-124. 
KLUGE, R. A.; COSTA, C. A.; VITTI, M. C. D.; ONGARELLI, M. G.; JACOMINO, A. P.; MORETTI, C. L. Armazenamento refrigerado de beterraba minimamente processada em diferentes tipos de corte. Ciência Rural, Santa Maria, v. 36, n. 1, p. 263-270, 2006.

KLUGE, R. A.; GEERDINK, G. M.; TEZOTTOULIANA, J. V.; GUASSI, S. A. D.; ZORZETO, T. Q.; SASAKI, F. F. C.; MELLO, S. C. Qualidade de pimentões amarelos minimamente processados tratados com antioxidantes. Semina: Ciências Agrárias, Londrina, v. 35, n. 2, p. 801-812, 2014.

Kluge, R. A.; PICOLI, A. A.; AGUilA, J. S. Respiração e produção de etileno em beterrabas inteiras e minimamente processadas submetidas a tratamentos com etileno e biorreguladores. Horticultura Brasileira, Brasília, v. 28, n. 1, p. 54-57, 2010.

MATTIUZ, B.; MigUEL, A. C. A.; NACHTIGAL, J. C.; DURIGAN, J. F.; CAMARGO, U. A. Processamento mínimo de uvas de mesa sem semente. Revista Brasileira de Fruticultura, Jaboticabal, v. 26, n. 2, p. 226-229, 2004.

MAY, A.; TIVELLI, S. W.; VARGAS, P. F.; SAMRA, A. G.; SACCONI, L. V.; PINHEIRO, M. Q. A cultura da couve-flor. Campinas: Instituto Agronômico, 2007. 36 p. (Série Tecnologia APTA, Boletim técnico IAC, 200).

MICELI, A.; ROMANO, C.; MONCADA, A.; ANNA, F.; VETRANO, F. Effect of cold storage on the quality of minimally processed cauliflower. Carpathian Journal of Food Science and Technology, Cluj Napoca, v. 7, n. 2, p. 70-74, 2015.

MINOLTA, K. Comunicação precisa da cor: controle de qualidade da percepção à instrumentação. Osaka: Konika Minolta Sensing, INC, 1998. 59 p.

NELSON, N. A. A photometric adaptation of Somogy method for the determination of Glucose. Journal Biological Chemistry, Bethesda, v. 153, n. 2, p. 375-380, 1944.

OLARTE, C.; SANZ, S.; ECHÁVARRI, F. J.; AYALA, F. Effect of plastic permeability and exposure to light during storage on the quality of minimally processed broccoli and cauliflower. LWT - Food Science and Technology, Zürich, v. 42, n. 1, p. 402-411, 2009.

PELLEGRINI, N.; CHIAVARO, E.; GARDANA, C.; MAZZEO, T.; CONTINO, D.; GALLO, M.; RISO, P.; FOGLIANO, V.; PORRINI, M. Effect of different cooking methods on color, phytochemical concentration, and antioxidant capacity of raw and frozen brassica vegetables. Journal of Agricultural and Food Chemistry, Munich, v. 58, n. 7, p. 4310-4321, 2010.
RINALDI, M. M.; BENEDETTI, B. C.; MORETTI, C. L. Atividade respiratória, produção de etileno e vida útil de repolho (Brassica oleracea, var. capitata) minimamente processado em atmosfera controlada. Engenharia Agrícola, Jaboticabal, v. 28, n. 3, p. 579-589, 2008.

RINALDI, M. M.; BENEDETTI, B. C.; SARANTÓPOUlOS, C. I. G. L.; MORETTI, C. L. Estabilidade de repolho minimamente processado sob diferentes sistemas de embalagem. Ciência e Tecnologia de Alimentos, Campinas, v. 29, n. 2, p. 310-315, 2009.

RUSSO, V. C.; DAIUTO, E. R.; SANTOS, B. L.; LOZANO, M. G.; VIEITES, R. L.; VIEIRA, M. R. S. Qualidade de abóbora minimamente processada armazenada em atmosfera modificada ativa. Semina: Ciências Agrárias, Londrina, v. 33, n. 3, p. 1071-1084, $2012 \mathrm{a}$.

RUSSO, V. C.; DAIUTO, E. R.; VIEITES, R. L. Melão amarelo (CAC) minimamente processado submetido a diferentes cortes e concentrações de cloreto de cálcio armazenado em atmosfera modificada passiva. Semina: Ciências Agrárias, Londrina, v. 33, n. 1, p. 227-236, 2012b.

SIGRIST, J. M. M. Estudos fisiológicos e tecnológicos de couve-flor e rúcula minimamente processadas. 2002. Tese (Doutorado em Fitotecnia) - Escola Superior de Agricultura Luiz de Queiroz, Piracicaba.

SILVA, A. V. C.; OLIVEIRA, D. S. N.; YAGUIU, P.; CARNELOSSI, M. A. G.; MUNIZ, E. N.; NARAIN, N. Temperatura e embalagem para abóbora minimamente processada. Ciência e Tecnologia de Alimentos, Campinas, v. 29, n. 2, p. 391-394, 2009.

SIMÓN, A.; GONZÁLEZ-FANDOS, E.; RODRÍGUEZ, D. Effect of film and temperature on the sensory, microbiological and nutritional quality of minimally processed cauliflower. International Journal of Food Science and Technology, London, v. 43, n. 9, p. 16281636, 2008.

SOMOGY, M. Determination of blooded sugar. Journal Biologic Chemical, Baltimore, v. 160, p. 69-73, 1945.

SOUZA, A. M. de; GIOPPO, M.; GONÇALVEZ, J.; AYUB, R. A.; REZENDE, B. L. A.; OTTO, R. F. Caracterização pós-colheita de dois híbridos de couveflor. Revista Biotemas, Florianópolis, v. 23, n. 2, p. 45-49, 2010 . 
